\title{
Dynamic Theory Of The Money Market, Disposable Money And Interest
}

\author{
José Villacís González., University San Pablo CEU, Madrid, Spain
}

\begin{abstract}
To understand the money market one has to understand the different ways in which income circulates, specifically the amounts of money that are disposable, together with the dynamic supply of money and circulating capital. These three items all depend on the basic equation of macroeconomics, which is that savings equal investment, affecting it and completing it. This is the underlying principle of the theory of money and the rate of interest. The money market comprises those that want money, whether to engage in business or to speculate, and the money that is there to be had, i.e. money for sale, institutional money and bank money. Part of the theory of money was developed in the period between 1916 and 1925 by Germán Bernácer (Alicante, Spain 1883$1965)$ and differs from Keynesian ideas and modern macroeconomics.
\end{abstract}

Of the commodities that are easy to dispose of, none surpasses money.

(Germán Bernacer: How Money Works, 1945)

\section{INTRODUCTION}

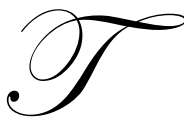

he approach used in this essay is as follows. First, money is sorted on the basis of the part it is playing in the production process, i.e., whether it is disposable money or money already tied up in production. From there we move on to the payments made by companies for the value added in the production process and, also, on the surplus that arises from national production, i.e. the domestic product. These payments finance productive activities and we call them here circulating capital of the second level.

Thus, on one side of the basic equation we have the savings pertaining to the period and the money created while, on the other, we have the investment and the added production obtained in the same period. What this means in practice is that we add to the normal equation savings = investment the money created and the circulating capital employed, thus completing it in a dynamic, temporal sense.

This formula is then applied to the demand for and the supply of money, which together define the money market, the assets it comprises, and the rate of interest.

\section{STOCKS OF DISPOSABLE MONEY}

Disposable money is that part of income over which free choice can be exercised and which constitutes, depending on its position and use, full control over the market. In a strictly monetary sense, it that part of income with which consumers, producers and savers can carry out whatever transaction they care to undertake but which, until they do so, remains disposable within the system. In essence it is the part of savings which is not capitalised. Depending on the extent to which each market participant has access to disposable money, the stock of disposable money will be greater or smaller. Given that there are financial assets which replicate money in the sense that their possession generates gains and interest, disposable stocks of money play a very important role.

The stocks available to consumers are mostly short-lived because they are required to meet basic needs, although even here a small surplus remains once this has been done. This available or disposable stock is called 'level one' stock. The stock of money available to the producer is 'level two' stock and is mostly used to pay for the running of the business: factors of production, maintenance, remunerating circulating capital and investment in fresh 
inputs. However, there is normally a surplus used to fund reserves, to offset depreciation or simply to save. Overall within the system there is thus an amount of free savings which is applied to neither consumption nor investment and which circulates freely, and frantically, in the secondary financial market amid second-hand financial assets and real assets that are not required for current production. These are the net or 'level three' disposable stocks of money, which we here denote by the letter ' $\mathrm{D}$ '. Disposable money circulates in the speculative market.

What this means is that of the free savings within the system part is invested and ceases to be disposable by becoming a fixed financial asset, while part remains free. The part that remains free constitutes the truly available or disposable stock of money.

Primary financial assets carry out the task of turning savings into investment and are both necessary and healthy for the system. They arose from income and production and they return there via investment. Not so the secondary financial assets, which are used for speculation and do not derive from current income and production: they are but the 'shadows' of wealth, and yet they constitute part of the income available for transactions.

At this point we must make clarify two things: first- and second-level disposable stocks of money are the parts of income that are used for undertaking transactions. They are relatively inelastic with respect to interest rates but heavily dependent on income. By their very nature they are short-lived because they are required by consumers and producers for their respective activities. 'Level-three' net disposable stocks, D, on the other hand, depend entirely on the rate of interest and on income and remain surplus to domestic or global product after the needs of consumption and production have been met.

It is very important to understand that there are flows and backflows of net or 'third-level' disposables, i.e. movements of income from the consumption and production markets to the speculative market and back again. Also, as this disposable stock arose from income, and income from production, D constitutes a subtraction from aggregate demand and thus a frustration of productive activity. This provides an explanation of the money market on one hand and, on the other, of the crises resulting from a period of intense activity in the speculative market.

The concept of disposables is similar to but different from the liquidity concept derived from Keynesian economics.

The usual formula is as follows: Production $=$ Income; Income - Consumption $=$ Savings.

At this point we depart from the usual formula on the grounds that not all savings are invested:

Savings - Investment $=\mathrm{D}$ (net or 'level three' disposables)

This circumstance was first revealed in 1916 by Germán Bernácer in his book Society and Happiness: An Essay on Social Mechanics, and explained in greater detail in the article The Theory of Disposables ... published in 1922. I incorporated the concept in modern macroeconomics in two stages: first in the book El Origen de la Macroeconomía ('The Origins of Macroeconomics') published in 1993 and then in the e-book: La Teoría de las Disponibilidades del Interés y de la Renta ('The Theory of Disposable Stocks of Interest and Income'), published in 2008.

\section{MONEY SUPPLY AND DEMAND}

In a market there is a demand for money and a supply of money. The former comprises those who give money and the latter those who take money, given that the market for goods and services presupposes a reciprocal and complementary exchange of money. This is the first stage of the money market; the second is the creation of private money by banks and companies and of legal money, i.e. legal tender, by central banks.

To this market we must add the market for primary and secondary financial assets, comprising those people supplying assets and taking money and those demanding assets and giving money. These supplies and demands must 
be added to the other supplies and demands of money. Of these, supply and demand of secondary financial assets falls outside the monetary circuit of production and consumption, i.e. actual production.

Here we should elaborate somewhat on the nature of primary and secondary financial assets. The former are necessary for investment and have a genuine macroeconomic role to play. The latter have no macroeconomic value as they do not form part of either production or the domestic product.

The rate of interest arises from the market for secondary financial assets, which is the supply and demand of net or 'level three' disposables, D, which fall outside production and consumption. Though they arise from income, which proceeds from production, not only do they circulate outside the circuit of production and consumption; by virtue of their percentage yield, interest, they attract a continually growing number of disposables. All net disposables that fail to return to production in the form of demand for goods or services depress the market.

From the result of the supply and demand of financial assets, i.e. the supply and demand of money for speculative purposes, arises the price or quoted value of financial assets, which we will call ' $\mathrm{V}$ '. If the return on these is measured by $\mathrm{R}$, the percentage return will be $\mathrm{R} / \mathrm{V}$, which is the rate of financial interest. This rate of interest acts as a magnet which detracts from consumption and, above all, from investment a certain proportion of income, i.e. those net disposables in search of the shadow of wealth.

The rate of interest that arises from the supply and demand of money, which is born from and for the current production of consumer goods and capital, is monetary interest, which acts as a valve that in no way opposes savings but attracts them and governs the proportion of savings which is capitalised. This interest is the result of the forces of production and demand. Crises arise from variations between financial interest and monetary interest.

\section{A COMMENT OF GERMÁN BERNÁCER WHICH NEEDS CORRECTING}

It should be clarified that the generation of income (or 'rent' in the old-fashioned terminology of Bernácer) refers to income that does not derive from domestic product or production and, also, that the market for rents to which we refer on occasions, refers to these secondary assets that do not generate production. That said, we can now better understand the words of Bernácer.

Germán Bernacer said in 1945, in his book La Doctrina Funcional del Dinero ('The Workings of Money'), nine years after publication of Keynes' The General Theory of Employment, Interest and Money, as follows:

If there were no market for rents, i.e., goods that have the property, the unnatural and artificial property, of producing an income for their owners, a market in which anyone in possession of disposables may obtain the right to enjoy a free rent thanks to their investment in such goods, interest would not exist and disposables would be capitalised in their entirety at zero interest. If a natural rate of interest exists, this is it.

What Bernácer is saying here is that the prevailing interest of the money market would be zero were it not for secondary financial assets and/or real assets that do not arise from current production. Firstly, because all rent would immediately return to production via the demand for goods and services. And, secondly, because there would be no such thing as interest.

However, Bernácer's argument is wrong, given that interest would exist regardless of the presence of a speculative market. Let us see why. Interest would be zero if the economy were stationary and neither production nor income grew. But as soon as production began to rise there would be a corresponding increase in the demand for money, firstly to consume and, secondly and most importantly, to invest and, in general, to create income, a demand that would be greater than the existing amount of money which, by definition, would be fixed. Money would thus become scarce and the interest rate would be higher than zero. In other words, money would have a price.

What this implies is that in order to achieve a dynamic economy it is necessary for the rate of interest to be zero but, paradoxically, the very nature of the economy thus created would result in a positive or non-zero rate of interest. 


\section{INTEREST IN A DYNAMIC ECONOMY}

In today's banking system the needs for the money required by a modern economy to finance the increases in income and production are met by either the companies themselves or the banks, or both, generating financial assets or debt instruments to fund the necessary purchases. The assets thus created are accepted as means of payment in an economy in need of money. There is a certain amount of inertia or tendency within an economy to generate means of payment in a proportion that does not match exactly the needs of production. Final production is thus the sum of the real and monetary added values of the system, which are aided in the process of their creation by this amount of additional money, though not always exactly in line with its precise value. At the same time, payments made between companies and payments made between banks, exercise the banking multiplier that creates bank money, which is different from the financial assets accepted as means of payment but much more liquid.

Between the two, companies and banks, enough money is generated as a natural consequence of the tensions pertaining to productive resources to enable production and income. And here we differ from the previous argument to say that a dynamic economy, though on one hand it results in the onset of interest, on the other, by generating money it obliges that interest to remain low. These arguments are independent of the creation of legal and institutional money by the central bank which, if it wished, could easily bring interest rates down to zero.

\section{PAYMENTS, CIRCULATING CAPITAL AND THE MONEY MARKET}

There are two kinds of circulating capital: one is the sum of the added values in a vertical sense generated in production, which gives us the value of final production. Defining the production segments by increasing alphabetical order, added values are given by the sum: $a b+b c+c d+d e+e f=a f$, which is the value of the end product. The sum of end products is the net domestic product. Each step in the production process requires a quantity of money which is recovered by the business owners when the end products, with their component parts of consumption and capital, are sold.

The situation is rather more complex when we come to the of the second kind. We say that between companies there is a series of payments in the order of added values in a horizontal or simultaneous sense. What this says $\mathrm{s}$ that there are companies that generate $\mathrm{ab}$ of added value, others elsewhere that pay ac, others in another sequence ac, others ae and other af. The total payments made within the system, which are not called added values) are:

$\mathrm{ab}+\mathrm{ac}+\mathrm{ad}+\mathrm{ae}+\mathrm{af}=\mathrm{L}$

The circulating capital of the second class is given by the difference between that of the first class and horizontal payments between companies:

$\mathrm{L}-\mathrm{af}=$ circulating capital of the second kind.

The payments among companies are worth $\mathrm{L}$, but the increase in production equals af (not $\mathrm{L}$ ).

We do not follow a vertical argument for a chain of companies that, for example, fell trees to turn them into paper. Instead, we use both the vertical and horizontal arguments of other companies. At no time are the same items counted twice. Circulating capital of the second kind is just as real as that of the first kind.

\section{SAVINGS AND INVESTMENT IN A DYNAMIC ECONOMY}

In a static economy, with nil growth, the savings that are invested do not depress the market. In a dynamic economy, they do. In other words, supply exceeds demand. Investment occurs when part of the savings within the system acquire the production of capital goods, a transaction that is attributed to demand. The transaction implies new production and generation of income from the value of said production. 
In such cases there are two volumes of production in the market: one is the production that was not purchased because of the saving; and the other is that deriving from the investment which places on the market certain fixed capital. Both are, in reality, circulating capital. But as opposed to this double production, there is only one generation of income, which is that produced by the spending implied by the investment. The net outcome is that demand is smaller than supply and the market goes into a depression, from which it may either recover its balance in a relatively short time by mothballing production capacity or go into a long-term depression in free fall.

The equilibrium of a dynamic economy requires new money to be generated within the system to support, via spending, the aggregate demand of the system which, as we saw, is smaller than the circulating capital generated. This argument confirms those stated in the two previous paragraphs.

The savings will acquire the production of capital and generate new production, which will join that which was not acquired to result in two volumes of circulating capital and only one volume of income. The new money must compensate demand by acquiring the circulating capital supplied but not sold.

As we have seen, there is a tendency in productive and commercial activities to use the banks and for these to employ their deposits, which results in the banking multiplier and, thus, the creation of money. Better still, there is a tendency which no one has been able to define exactly, and which is generally less marked, whereby the new money naturally joins forces with the circulating capital. There is also a tendency to use debt instruments as means of payment, i.e, as money when central banks fail to create sufficient legal money. But this creation of private money will very rarely be sufficient unless it is accompanied by a means of compensating financially for the creation of additional circulating capital. Unless this occurs, the system will reveal a demand for money in order to transact the new production, i.e. the previous and the new output. This will put pressure on the supply of money, assuming that the central bank does not intervene, which could precipitate the crisis.

It is precisely in boom times, when companies try hard to increase production, to the point where they exhaust their bank credit and resort to their own reserves, that the crisis becomes latent.

\section{CONCLUSION}

Two money markets are explained. In one the supply of and demand for money to fund production and receive the income obtained therefrom is involved. From the competing forces of supply and demand is born monetary interest. But there is another money market made up of disposable stocks of money which are not invested and which oscillate frantically in a speculative market that neither contributes to production nor generates domestic product. From this market arises financial interest, which operates against the capitalisation of savings.

It might be held, following Bernácer, that financial interest, or interest in general, would disappear if the speculative market were removed. This is not the case. A growing economy needs money to fund the increase in circulating capital, i.e. production, and the increase in demand for money would increase the amount of interest paid for it. The banking system tends to generate money by means of the banking multiplier working alongside the creation of circulating capital. However, it is necessary to create sufficient legal money to finance the presence of two volumes of circulating capital and avoid falling into a depression.

\section{AUTHOR INFORMATION}

José Villacís González. Member of the American Economic Association and of the Royal Spanish Academy of Doctors in Philosophy; lecturer in macroeconomics, University San Pablo CEU, Paseo Juan XXIII 6, 28040 Madrid, Spain.

\section{REFERENCES}

1. Azariadis, C. (1975): “A Reexamination of Natural Rate Theory”, American Economic Review, 71: 946-60.

2. $\quad$ Bernácer Germán (1916): "Sociedad y Felicidad”, Beltrán, Madrid, 1916.

3. (1922): “La Teoría de las Disponibilidades". Revista Española de Economía, Madrid, Barcelona. 
4. (1945): “La Doctrina Funcional del Dinero”. published by Consejo Superior de Investigaciones Científicas, Madrid.

5. Baumol William (1952): "The Transaction Demand for Cash: An Inventory Theoretic Approach". Quarterly Journal of Economics, 66 November.

6. Cagan, Phillips, (1956) “The Monetary Dynamics of Hyperinflation”, in "Studies in the Quantity Theory of Money", edited by Milton Friedman. Chicago, University of Chicago Press.

7. Feldstein Martin, (1980): “Comments on a Competitive Theory of Fluctuations and the Feastibility and Desirability of Stabilization Policy", in Rational Expectations of the Gramlih Study, Brooking Papers on Economic Activity, 1: 167-168.

8. $\quad$ Friedman M. (1956): "The Quantity Theory of Money; A Restatement”, in M. Friedman (editor) "Studies in the Quantity Theory of Money, Chicago, University of Chicago Press.

9. Friedman M. (1968): "The Role of Monetary Policy", American Economic Review, 58:1-17.

10. Grossman, S., and Joseph E.Stiglitz (1981): "Information and Competitive Stock Prices", American Economic Review, 66, pp. 246-53.

11. Hall, Robert E. (1976) "The Phillips Curvew and Macroeconomic Policy", in "The Phillips Curves and Labor Markets", edited by Karl Brunner and Allan H. Meltzer. Carnegie-Rochester Conference Series on Public Policy number 1.; Amsterdam: North Holland.

12. Keynes, J. M. (1936): “The General Theory of Employment, Interest and Money”. New York, Harcourt, Grace and World.

13. (1923) "A Tract on Monetary Reform", London, McMillan.

14. (1930)“A Treatise on Money”, London and New York: McMillan.

15. Kydland, Finn E., y Edward C.Prescott: (1977): "Rules Rather than Discretion: The Inconsistency of Optimal Plans", Journal of Political Economy, 85: 473-91

16. (1980):“A Competitive Theory of Fluctuations and the Feasability and Desirability of Stabilization Policy”, in Rational Expectation and Economic Policy, edited by Stanley Fisher; Chicago; National Bureau of Economic Research.

17. Laidler, D. (1966): "Some Evidence of the Demand for Money”, Journal of Political Economy, 74, 55-68.

18. (1968): "The Permanent Income Concept in a Macroeconomic Model", Oxford Economic Paper, 20 marzo, 11-23.

19. (1973): "Expectations, Adjustment and the Dynamic Response of Income to Policy Changes", Journal of Money, Credit and Banking 4 ,157-172. 1973.

20. Locke, J. (1692): "Some Considerations on the Consequences of the Lowering of Interest and Raising the Value of Money". London.

21. Mishkin, Frederik S. (1978): "Efficient-Market Theory: Implications for Monetary Policy", in Brookings Paper on Economic Activity, edited by Okun amd G.L.Perry. Vol. 3, pp 707-68.

22. Modigliani, F. Brumberg, R.E. (1954): "Utility analysis and the Consumption Function: An Interpretation of Cross-Section Data", en K.K. Kurihara, Post-Keynesian Economics, London, George Allen \& Unwin.

23. (1961): "Rational Expectations and the Theory of Price Movements", Econométrica, 29: 315-35.

24. Prescott, Edward C. (1977): "Should control theory be used for economic stabilization?" in Optimal Policies, Control Theory and Technology Experts, edited by Karl Brunner and Allan Meltzer. CarnegieRochester Conference Series on Public Policy; Amsterdam; North Holland.

25. Villacís, José. (1987): "Política Monetaria y Fiscal: una Paradoja de los Subrogados del Dinero". In Revista de Derecho Financiero y de Hacienda Pública. Volumen XXXVII, number 191 (September-October), Madrid.

26. (1990): “La Política Fiscal No Existe”. In Revista de Derecho Financiero y Hacienda Pública. Volumen XL - Number 205 (January/February). Madrid. 